\title{
Contribution of Tracers for Understanding the Hydrodynamics of Karstic Aquifers Crossed by Allogenic Rivers, Spain
}

\author{
Rafael Segovia Rosales, Eugenio Sanz Pérez and Ignacio Menéndez Pidal \\ Laboratorio de Geología Aplicada, Escuela Técnica, Superior de Ingenieros de Caminos \\ Canales y Puertos, Universidad Politécnica de Madrid
}

Spain

\section{Introduction}

Karstic aquifers provide a source of water supply over large parts of the Mediterranean region. Spain has many large karstic springs under natural regime that contribute to the base flow and quality of river water. Other aquifers are intensively exploited for human water supply, and their vulnerability to pollution needs to be defined and protection zones instated.

A large proportion of the karst systems are scarcely exploited and are under a near-natural regime. They are connected to rivers to a greater or lesser extent. Some of these large springs, such as La Galiana (Iberian Cordillera, Soria, Spain), represent the only drainage point from aquifers and contain significant high-quality water resources. They are responsible for the majority of the base flow of the rivers they give rise to, since the Mediterranean climate means that precipitation falls irregularly. These watercourses can also support a well-conserved aquatic fauna, whose survival depends largely on this base flow. These types of aquifer also require meaningful hydrogeological study and, specially, the knowledge of the hydrodynamics of the aquifer in general and their hydraulic conductivity in particular.

The relative influence of the geomorphological, geological and process factors determines the distribution of voids in the karst rock, and through that, the physical characteristics of effective porosity, hydraulic conductivity and specific storage.

Karstic aquifers are particularly vulnerable to pollution due, amongst other factors, to the presence of swallow holes through which polluted surface water can penetrate. In addition, polluted water circulates rapidly through conduits that possess little capacity for selfpurification, transporting the polluted water over large distances. (COST 65; Goldscheider et al. 2000; Zwahlen, 2004; Goldscheider, 2005; Panno, 2006; Fournier et al. 2007).

The study area dealt with in this paper lies in the northwest of the Iberian Cordillera (Central Spain) and extends over approximately $400 \mathrm{~km}^{2}$. Its relief is determined by the presence of a meseta of limestone layers that have been dissected by the River Lobos, giving rise to a canyon 26 kilometres long. In 1985, this was declared a Natural Park, due to its peculiar landscape and an important colony of Griffin Vultures, as well as colonies of other birds of prey like the Golden Eagle (C.M.A. - J.C.L., 1992). The River Ucero emerges from a 
spring at La Galiana situated at the end of the canyon, with a mean flow of some $2000 \mathrm{l}$ /s. The Ucero is a right bank tributary of the river Duero. In turn, the river Lobos has a series of left-bank tributaries whose headwaters lie outside of the calcareous massif in the less permeable rocks around its perimeter.

Of the fish species present, the common trout is common and the river Ucero is one of the most productive in Spain, being famous as a trout stream ever since Medieval times. With respect to mammals, there are nearly thirty species represented, including otter, mountain cat, beech marten and roe deer. The presence of the otter is linked to the abundance and quality of the water. The majority of species depend on the deep pools of the Lobos to survive the summer. The Lobos itself, whose flow is not regulated, has a natural regime, ranging from the flood flows in winter and spring (which, in the narrowest reaches can cover the entire bed of the canyon) to a river bed that is dry except for the deep pools where the water table comes to the surface. The fauna are adapted to this dynamic - the yellow water lily, for example, which seems to be swept away by the winter flows, reappears each spring in the quiet backwaters. Even during the most unfavourable months of high summer, the largest deep pools still have water, whilst the rest of the watercourse is practically dry. As intimated above, it is essential to conserve the animal communities that depend on the deep pools.

Most of the Cretaceous aquifers and their recharge areas fall within the boundaries of the Natural Park. One of the main objectives of declaring the Natural Park was to conserve its waters and achieve compatible use of the aquifer as a groundwater reserve for supply high-quality water to the centres of population in the vicinity. Although the groundwater resources of the Weald Facies around the periphery of the karst would be sufficient in quantity to satisfy current demand, they are mostly degraded by the naturally poor quality of water, due to its high iron content. For this reason, the karstic aquifer of the Lobos Canyon assumes greater importance as a water resource and as a significant water reserve suitable for human consumption, which needs to be protected from contamination.

The object of this study was to provide a sufficiently detailed knowledge of the aquifer in a short time, bearing in mind the scarcity of data available. The methodology applied gave good results, yielding quite a clear model of its hydrogeological behaviour. The study is based on two preliminary studies of the geomorphology and hydrogeology, on the geological maps for the aquifer (only available on a scale of $1 / 50.000$ ), and on data from a handful of drinking water supply wells. For this reason, it was necessary to devise a plan of work that could yield quantitative knowledge and include aspects important to the future management and conservation of the aquifer and its rivers, such as understanding the flow and hydrodynamics of the aquifer.

These tests of tracers can be the basis for estimating the hydraulic conductivity, because there is a direct relationship between the groundwater velocity and hydraulic conductivity. This research shows how hydraulic conductivity presents spatial variation with regards to variations of the karstification.

Existing wells are few and insufficient to draw an isopiezometric map. However, the aquifer is suitable for tracer studies because of its numerous sinkholes. In fact, there have been several qualitative antecedents with positive results, which have endorsed the viability of tracer experiments (Hernanz y Navarro, 1972; Sanz, 1992, 1996). It was hoped that tracer tests would determine how groundwater velocity varies under different rainfall regimes 
and with distance from the discharge point, and throw light on the dispersion of contaminants within the aquifer.

Another important aspect was de determine the response of the aquifer to pollution. The autogenous recharge area of the aquifer is mostly covered by woodland and there are no pollution foci. Rather, the risk of pollution hails from discharges to allogenous rivers as they flow through towns and villages before reaching the karst. There have been cases of illegal discharges of purines from pig farms during the 1970s and 1980s, which reappeared through La Galiana spring, as well as sewage spills from towns and villages upstream.

Thus, it is important to have a detailed understanding of the relationship between the river Lobos and the karstic aquifer under different hydrological situations, since this river flows from one side of the aquifer to the other and is the collector stream for all the surface watercourses. It was not known if the river behaved solely as a losing stream along its entire length, nor what the infiltration capacity of the riverbed was. The riverbeds hydraulic conductivity of these streams determines the recharge of these allogenic streams. Tracer studies were needed to elucidate the hydraulic connection between the rivers and the aquifer and two temporary gauging stations were installed in the river Lobo, as well as three on its tributaries and one at La Galiana spring.

\section{Hydrogeology of the karst of the river Lobos canyon}

\subsection{Geology}

Sedimentary terrains in the Natural Park date from the Jurassic to the Present Day. The Jurassic rocks are essentially marine carbonate rocks. Overlying these, concordant with them and in transition towards the Cretaceous, are detritic sediments of the Purbeck-Weald Facies. Over these, lie sands of the Utrillas Facies (Albian), then Coniacian-SantonianCampanian marls, and the Turonian limestones, which project to form the surface relief, and the cliff faces of the canyons in this region (including the canyons of the rivers Lobos, Espeja, Abión en Burgo de Osma and Boos). Above these strata comes the Garumnian Facies in transition with the Tertiary and, discordantly, the postorogenic sediments of the Miocene, Plioquaternary and Quaternary (IGME, 1982).

\subsection{Definition of the karstic aquifer}

The Coniacian-Santonian-Campanian limestones are $240 \mathrm{~m}$ thick and comprise a highly permeable hydrostratigraphic unit that forms the main aquifer. Its impermeable base consists of a marly series with calcareous intercalations towards the top, some $70-100 \mathrm{~m}$ thick.

Due to the presence of the marly intercalations, the lower part of the aquifer can be locally confined, while the rest is classified as a free aquifer, forming a meseta, with a syncline structure oriented east-west. Its lateral borders are defined by impermeable Cretaceous marly outcrops that also define the base of the aquifer, except in the south, where there is a discordant contact between the clayey Miocene and the calcareous Upper Cretaceous. The anticlinal axis of Santa María de las Hoyas-Ucero-Ailagas raises the marly base and, whilst it does not always outcrop, it forms the hidden lateral barrier. The hinge and axis of the anticline form the underground watershed between the Lobos aquifer in the north, and the one to the south that feeds the springs at Rejas, Fuencaliente and Ucero. This behaviour was deduced from elevations, as indicated in the block diagram in figure 1. 


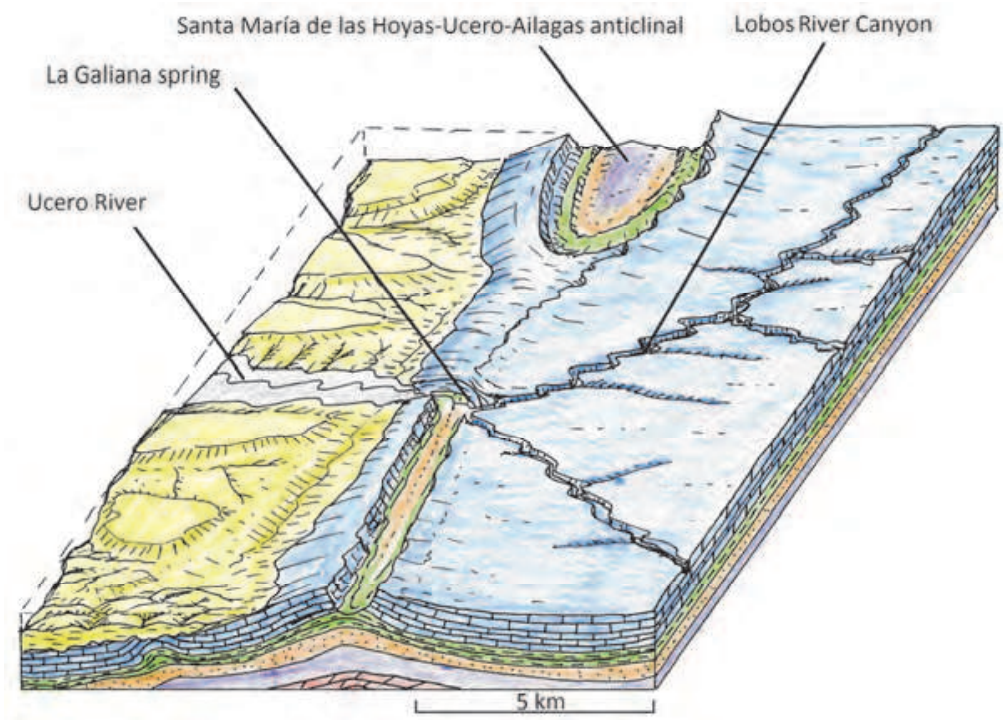

Fig. 1. Block diagram showing the southern part of Lobos River Canyon aquifer (E. Sanz). Green: Cretaceous marls. Blue: Cretaceous limestone (aquifer). Yellow: Tertiary clay.

The eastern border may be open towards Torreblancos, where a number of springs emerge carrying flows of $200 \mathrm{l} / \mathrm{s}$. For this reason, it was decided to define the limit of the system there, where the Cretaceous is still covered by the Tertiary. The possibility of a hydraulic connection with the Tertiary of the Almazán Basin cannot be ruled out.

The marls mentioned above mark the base of the karst, and surround the synform on almost all sides. La Galiana spring emerges at a lower elevation (approximately $900 \mathrm{~m}$ a.s.l., at the entrance to the Lobos Canyon, upstream of Ucero), where the karst meets these marls.

The carbonate rocks outcrop over some $160 \mathrm{~km}^{2}$ and represent the erosion surface of the meseta (SEF). As the SEF dates from the end of the Miocene, it means that these rocks have been exposed to karstification since this time. There are neither poljes nor uvalas, and dolines are infrequent. More abundant are karren fields. With respect to the endokarst, there is an overwhelming dominance of sinkholes over caves, and the only caves are restricted to former or present-day discharge points of the aquifer, all of which are concentrated at La Galiana, at the end of the canyon. The homogeneous distribution of the abundant sinkholes throughout the massif suggests recharge is predominantly diffuse, rather than concentrated.

Terra rossa soil is concentrated at the base of the slopes, in the stream beds, dolines and infilled fissures. Rendzina soils are dominant and have developed over the limestone. They contain more than $40 \%$ carbonate, and have a significant humus content, which has encouraged a shrubby vegetation cover of pine and juniper woodland.

\subsection{Characterization of natural recharge and water balance of the aquifer}

The Lobo catchment can be divided into two zones with distinct hydrogeological characteristics. The first contains Wealden deposits and Jurassic carbonates $\left(197 \mathrm{~km}^{2}\right)$. These are located in the north and northeast and comprise mostly detritic deposits (Wealden), with 
a narrow band of Jurassic carbonates. Its outflows, both surface runoff and groundwater (or hypodermic) base flow, flow into the karst, since the headwaters of the rivers Lobos, Navaleno, Chico and others all flow into the Lobos karstic zone.

The second zone is the karst $\left(164 \mathrm{~km}^{2}\right)$ in the south and southeast of the catchment and defined by low permeability deposits. This zone receives slightly less rainfall than the first. It discharges mainly towards La Galiana spring. The zone does not produce its own surface runoff, except after very intense rainfall. In addition to recharge from rain falling over its outcrops, it receives all of the runoff from the Wealden/Jurassic zone. When the flow from the Wealden/Jurassic zone exceeds the infiltration capacity of the riverbeds (of the river Chico and, especially, the river Lobos), the excess surface water leaves the karstic system via the river Ucero.

The water balance calculated for the period (during which the aquifer was under natural regime) was reported by Segovia (2008) and showed rainfall of $109.5 \mathrm{hm}^{3}$, natural recharge of $77 \mathrm{hm}^{3}$, evapotranspiration of $64.3 \mathrm{hm}^{3}$, and practically nil pumped water abstractions, zero surface runoff and zero lateral transfers to other aquifers. The water stored in the aquifer increased by $5.59 \mathrm{hm}^{3}$.

Allogenous recharge was differentiated from autogenous using data from the temporary gauging stations on the allogenous rivers. In this way, over the study period, autogenous recharge was calculated to be $42.2 \mathrm{hm}^{3}$, or $54 \%$ of the total recharge. Allogenous recharge was calculated to be $31.5 \mathrm{hm}^{3}$, or $41 \%$ of the recharge. For the Lobos catchment as a whole during this period, $\mathrm{R}=77 \mathrm{hm}^{3}$, which represents $32 \%$ of the precipitation. The recharge rate with respect to precipitation in the karstic zone ( $R k$ ) was $R_{k}=41 \%$, and $R_{w}=24 \%$ in the allogenous zone.

The sole discharges of the aquifer are via La Galiana spring, and through the river bed of the Lobos upstream of this spring, where discharge takes the form of permanent pools, interconnected by only a small stream of water under dry weather conditions, or by an appreciable current in times of mid to high water (10 to $601 / \mathrm{s})$.

These outflows were monitored at a gauging station downstream, to reconstruct the hydrogram for the hydrological year 1995 - 1996 (1 September 1995 to 31 August 1996). The mean flow was 2,423 l/s, the great majority of which flows from the Galiana spring, and the remainder from the river Lobos discharges $4-5 \mathrm{~km}$ upstream.

As seen from figure 2, La Galiana spring has an irregular flow that is highly sensitive to rainfall and snow melt, indicating quite a rapid emptying of the aquifer. The spring at La Galiana reacts to heavy rainfall events with a delay of 4 or 5 days. This time lag is logical in large karstic aquifers like this one, where there is a delayed reaction to recharge to allogenic streams situated on the periphery at moderate or long distance. In addition, the allogenic recharge has to penetrate the $100 \mathrm{~m}$ thickness of the unsaturated zone. (This phenomenon is confirmed, to a certain extent, by the dripping from stalactites in the Lower cave at La Galiana after rainfall events (Sanz, 2000).

\subsection{Hydrodynamic functioning}

\subsubsection{Flow monitoring}

The synclinal structure determines that groundwater flow converges and accumulates in its centre, where the Lobos Canyon is set. In this way, the lower reach of the canyon acts as the natural drain, creating the patent and visible discharge at La Galiana, described above.

Tracer studies were required to determine the hydrodynamics of the aquifer, since the aquifer is under a natural regime and there is insufficient piezometric data from boreholes (there are only three boreholes) to draw isopiezometric maps. 


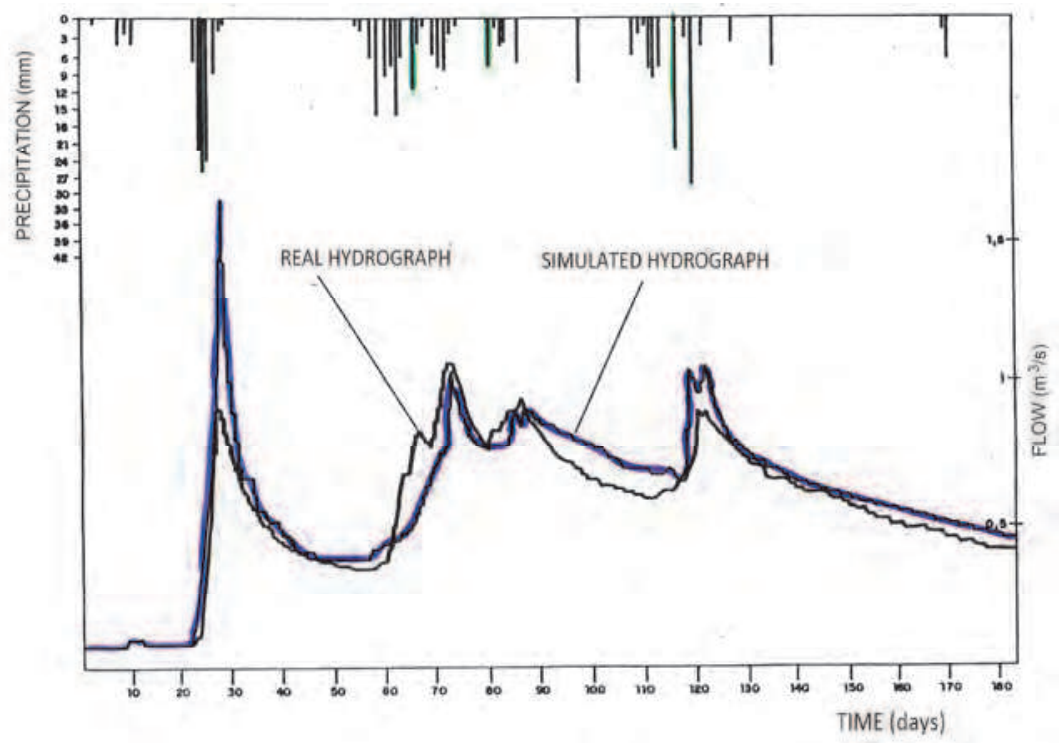

Fig. 2. Real and simulated hydrograms in 1989

\subsubsection{Hydraulic gradient}

Though no isopiestic map was available, the hydraulic gradient can be estimated using the elevation of the spring at La Galiana $(900 \mathrm{~m}$ ), in addition to the boreholes (at Puente de Siete Ojos, future supply wells for San Leonardo, Navaleno and Casarejos, and the well serving the bar within the canyon). Furthermore, swallow holes containing permanent water (like Valdecea) can be used because deep sinkholes that are always dry give us the maximum hydraulic gradient. They also give the longitudinal gradient of the course of the river Lobos, which provides a value for the maximum hydraulic gradient under high water conditions, where they act as collectors.

In this way, the following gradients were calculated: under high water conditions, the gradient could be around 2.5 per thousand (0.0025), whilst under low water (dry season), it could be 0.62 per thousand $(0.00062)$.

\subsubsection{Variation in phreatic level}

It is well known that karstic aquifers can suffer sharp piezometric oscillations, since their porosity is relatively low but their recharge capacity is large - so that they can fill very quickly.

Variation in the phreatic level is also indirectly reflected by oscillations and sharp changes in flow seen in the hydrogram for La Galiana de Ucero.

Though no periodic piezometric measurements were available, the following observations have been made about variations in piezometric level (Sanz, 1992)

- The water level in a $25 \mathrm{~m}$ borehole on the talweg of the river Lobos at Puente de Siete Ojos, which is usually dry, rose quickly (in less than a week) following intense rain during December 1995/January 1996, reaching the same level as the river itself.

- Appearance of the resurgences at Las Raideras. 
- $\quad$ Rapid rise of more than $20 \mathrm{~m}$ in the cave at Hue Seca de Valdeavellano (a gallery that is normally dry to at least $20 \mathrm{~m}$ depth and $400 \mathrm{~m}$ length) which began to discharge after intense rain. Here, a spring bursts forth from the cave mouth, carrying up to $100 \mathrm{l} / \mathrm{s}$ that forms the headwater of a stream.

- The swallow hole at Hue Seca, in Santa María de las Hoyas, is $11 \mathrm{~m}$ deep and usually dry, but it produces a flow that can exceed $200 \mathrm{l} / \mathrm{s}$ as the phreatic level rises during exceptionally rainy spells. The flow usually persists only a few days and then the water level in the swallow hole recedes slowly, until the stream dries up.

\section{Methodology}

Ten tracer tests were carried out by dosing uranine in sinkholes between 5 and $14 \mathrm{~km}$ distance from each other. The tests were done in both low water and flood conditions during the hydrological year 1995 - 1996, a year that included both severe low water and a sudden winter recharge. A further test was done in the sporadic springs of Las Raideras via a connected sinkhole with the phreatic level at its base.

Monitoring and sample collection was done at the presumed emergence points of the tracer, i.e. at La Galiana spring, at a fish farm on the river Ucero, and at a point on the river Lobos. At the latter point, samples were taken upstream of the surgence (when there was any flow in the river). During the dry season, the lower reach of the river Lobos carries only a small volume of groundwater discharge. However, during the wet season, it was not known what connection the river flow has to the aquifer, nor its relevance. Samples were collected twice a day, giving a total of 700 samples, which was considered sufficient given the extended duration of the tests. In all cases, correct authorization had been obtained (though the tracer plumes were invisible to the human eye and so passed unnoticed by members of the public). Laboratory analysis employed precision fluoroscopy, with some samples being analysed for $\mathrm{pH}$ and conductivity as well. Fluocaptors were also installed in the springs at Fuencaliente, Rejas and Santervás, situated on the periphery of the karst, in order to check that there was no communication between these and the sinkholes used in the tracer test.

In karstic aquifers where there are few boreholes that can be used to draw isopiestic maps and understand groundwater flow, tracer studies can be used to understand the hydrodynamics of the system and other aspects, such as vulnerability to pollution.

In hydrogeology as well, quantitative experiments have been carried out to obtain the response curves (for example, Smart, (1988), Hauns et al.(1991), Meus and Bakalowicz, M. (1997), Käss (1998), Birk et al. (2005), Massei et al. (2006), Geyer et al. (2007), Morales et al. (2007), Goldscheider et al.(2008), Göppert and Goldscheider(2008), Perrin and Luetscher (2008) ). G-Yélamos (1999) presents a clear summary of these kinds of experiments in Spain. In the present case, the choice of this method is clearly justified, since we are dealing with a practically unexploited aquifer, with numerous permanent and temporary swallow holes distributed at various distances from the principal discharge point at La Galiana.

The methodology followed for the tracer tests during 1995 and 1996 involved the injection of a total of 5,100 g of uranine through nine different injection sites, selected according to the location of sinkholes and the hydrogeological knowledge available.

Injection sites were selected in order to elucidate the influence of orientation with respect to the spring at La Galiana. In addition, sinkholes were selected at different distances from the spring, to investigate the velocity and dispersion of the tracer. In addition to these two aspects of spatial distribution, tests were also distributed temporally, to determine variation 
in flow velocity under different hydrological situations (low and high water conditions, for example). The points selected are indicated in the following table 1 and on Figure $3 \mathrm{We}$ consider that this range of distances and orientations is representative, given the possibilities offered by the aquifer.

\begin{tabular}{|c|c|c|c|c|c|c|c|}
\hline Injection Site & $\begin{array}{c}\text { Distance to } \\
\text { spring at } \\
\text { La Galiana } \\
(\mathrm{km})\end{array}$ & Date & $\begin{array}{l}\text { Mass of } \\
\text { tracer } \\
\text { injected } \\
\text { (gr) }\end{array}$ & $\begin{array}{l}\text { Mean } \\
\text { time to } \\
\text { appear } \\
\text { (days) }\end{array}$ & $\begin{array}{c}\text { Mean } \\
\text { flow at La } \\
\text { Galiana } \\
(1 / s)\end{array}$ & $\begin{array}{c}\text { Time } \\
\text { tracer } \\
\text { was } \\
\text { within } \\
\text { aquifer } \\
\text { (days) }\end{array}$ & $\begin{array}{c}\text { Velocity } \\
\text { (km/day) }\end{array}$ \\
\hline $\begin{array}{c}\text { River } \\
\text { Navaleno } \\
\text { sinkhole } \\
\end{array}$ & 9,5 & $5 / 10 / 1995$ & 200 & 12 & 2.600 & 18 & 0,8 \\
\hline $\begin{array}{c}\text { River Chico } \\
\text { sinkhole }\end{array}$ & 6,5 & 11/11/1995 & 300 & 14 & 2.300 & 30 & 0,46 \\
\hline $\begin{array}{c}\text { River } \\
\text { Navaleno } \\
\text { sinkhole } \\
\end{array}$ & 9,5 & 17/12/1995 & 500 & 8,5 & 1.400 & 18 & 1,1 \\
\hline \multirow{2}{*}{$\begin{array}{c}\text { Sinkhole in } \\
\text { Arroyo de } \\
\text { Valderrueda } \\
\text { (de Casarejos) }\end{array}$} & $\begin{array}{r}4,5 \\
\end{array}$ & $28 / 12 / 1996$ & 600 & 3 & 3.000 & 10 & 1,5 \\
\hline & $\begin{array}{l}1 \text { (distance } \\
\text { to river } \\
\text { Lobos) }\end{array}$ & 28/12/1996 & 600 & 1 (approx) & 3.000 & hours & 4 \\
\hline $\begin{array}{c}\text { Sinkhole in } \\
\text { Arroyo del } \\
\text { Chorrón }\end{array}$ & 10 & 4/1/1996 & 1.400 & 4,5 & 4.600 & 21 & 2,2 \\
\hline $\begin{array}{c}\text { Sima de } \\
\text { Valdecea }\end{array}$ & 2,5 & $17 / 2 / 1996$ & 500 & $<1$ & $3.0 ? 00$ & 4 & 3 \\
\hline $\begin{array}{l}\text { sinkhole in } \\
\text { the river } \\
\text { Lobos } \\
\text { (Apretadero) } \\
\end{array}$ & 12 & 13/3/1996 & 1000 & 21 & 2.200 & 15 & 0,6 \\
\hline
\end{tabular}

Table 1 . Some value obtained by tracers testing

\subsection{Tracer injections made}

Prior to the current investigation, two other tests had been done in the river Navaleno (16 August 1967) and in the river Chico (1992). In both cases, the uranine reappeared at La Galiana. The 1967 test formed part of research into karstic aquifers by the Centre for Hydrographic Studies, and consisted of a single dose of $3 \mathrm{~kg}$ uranine dissolved in alcohol and ammonia in a swallow hole in the bed of the river Navaleno, $9.5 \mathrm{~km}$ from the spring at La Galiana (Figure 3, measured as the crow flies). The dye re-emerged at La Galina after 6.5 days. The dye tracer test in the river Chico was done 1991. These preliminary tests provided orientation when planning the 1995-96 dye tracer survey.

\subsection{Sampling}

Water samples were taken periodically at La Galiana spring, and fluocaptors were also used at the springs of Rejas de Ucero, Valdelinares, Fuencaliente and Sentervás, in case the aquifer had any outflow, apart from the river Ucero, on its south-western edge. The tracer was recovered only from the spring at La Galiana, which indicates that most or all of the discharge from the karst emerges at this spring. 
Samples were taken from the spring at La Galiana, from the river Lobos upstream of the springhead (since water also surcharges here) and, on occasions, from the fish farm downstream of the spring (which could be considered as the spring in its own right when the river Lobs does not carry any surface runoff).

Samples were taken in sterilized translucent plastic bottles $(100 \mathrm{ml})$ twice a day (morning and afternoon), and more frequently for the injection sites close to La Galiana. Samples were stored in the dark to avoid photodegradation of the tracer and to reduce microbial activity, both of which could have reduced the concentration of the tracer in the samples.

Samples were analysed by measuring the sodium fluorescein spectra using a luminescence spectrometer. This was equipped with synchronized scanning, which allows conjunctive analysis of both the excitation and emission spectra (fluorimeter). Analyses were done within one month of the samples being taken, in the Centro de Estudios de Técnicas Aplicadas del CEDEX (Madrid) and in the ETSCCP Applied Geology Laboratory of the Universidad Politécnica de Madrid. A "zero" reference solution was used, corresponding to the concentration of fluourescein present in the spring water at La Galiana at the start of the dye tests. By this means, any background effect due to earlier tests is eliminated.

\section{Results and discussions}

Figure 3 shows the trajectories of groundwater confirmed by the tracer tests, while Figure 4 shows the response curves. From Figures 3 and 4 we can make the following observations:

1. Confirmation of the hydrogeological catchment

The tracer tests confirmed the recharge area, previously established from geological maps, and identified the boundaries of the aquifer. They verified the communication between all the swallow holes and the spring at La Galiana, and confirmed that there are no lateral transfers to the springs of Funcaliente, Santervás and Rejas de Ucero, situated to the south. The only zone of discharge is La Galiana spring - and the lower reach of the river Lobos connected to this spring, which, in effect, forms part of the same discharge.

2. Relationship of the river Lobos with the aquifer as observed using tracer tests.

Under low water conditions, groundwater flow is towards La Galiana spring only, since the river Lobos remains dry over its entire length, except for a number of deep pools where the phreatic level comes to the surface, from downstream of the San Bartolomé hermitage, over a stretch of approximately $4 \mathrm{~km}$. The dye appeared only in La Galiana, in the form of a unimodal curve (Figure 4 and 5).

In times of intermediate flows, (neither dry season nor flood flows) which is the most common situation, the phreatic level rises and the lower reach of the river Lobos becomes a secondary surcharge for the aquifer, acting as a kind of overflow for La Galiana. This involves a flow between the pools of no more than $30 \mathrm{l} / \mathrm{s}$, since the majority of the flow continues to emerge via La Galiana. The rest of the river Lobos watercourse, upstream of the hermitage, is a losing stream. In the intermediate flow situations, dye also emerged in the river Lobos. When sampling was done in the river Ucero, downstream of La Galiana and the river Lobos, the response curves were bimodal, a smaller peak presaging these two outflow plumes (Figure 5). When samples were taken in the river Lobos and at the Galiana spring, separately and together, it was observed that the tracer appeared first in the river Lobos and, later, at La Galiana. This makes sense, since the river Lobos sampling points are upstream of the spring. In the test where dye was injected into the Apretadero sinkhole, the delay at La Galiana with respect to the river Lobos was two days (Figure 6). 


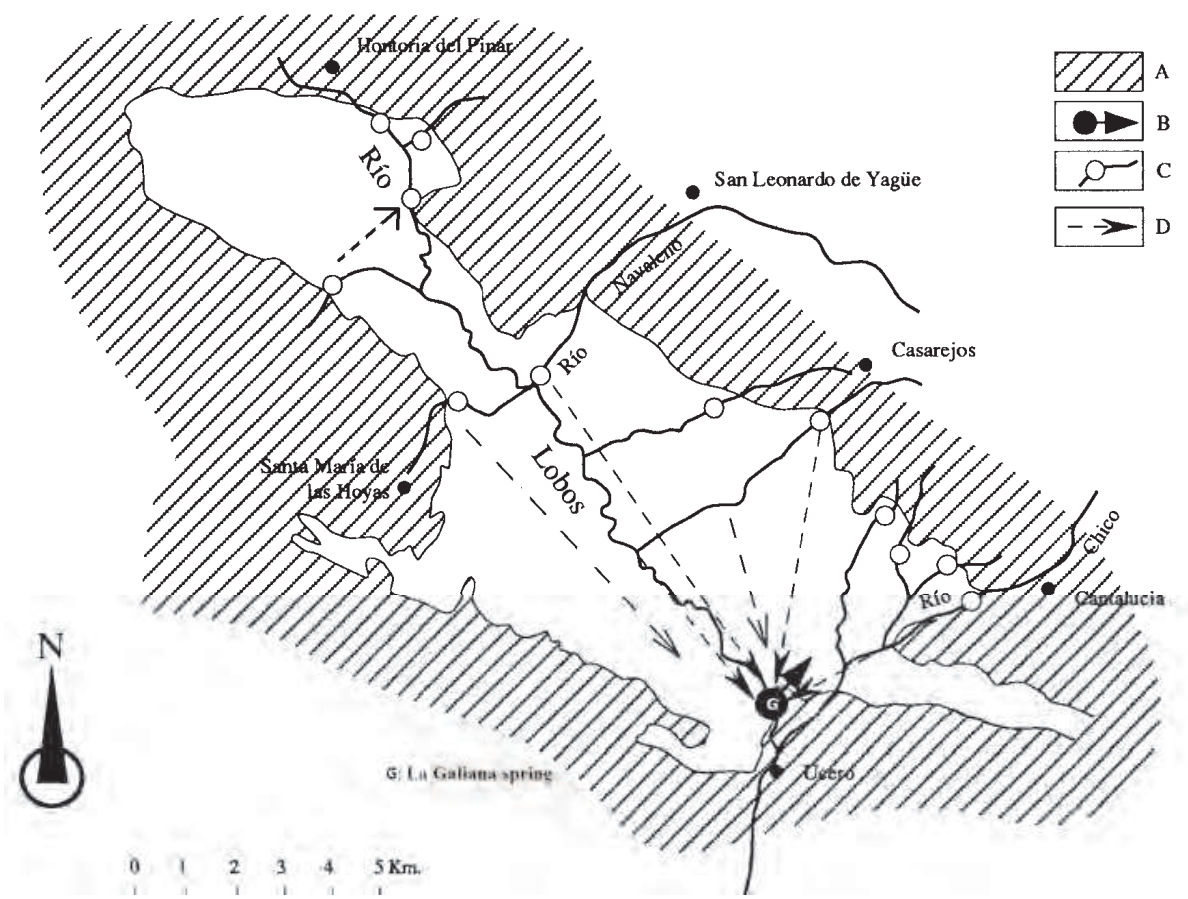

Fig. 3. Hydrogeological scheme at Lobos River Canyon and groundwater paths tested with tracers. A. Non-karst rocks. B. La Galiana spring. C. Connection proven by tracer. D. Streams with sinks

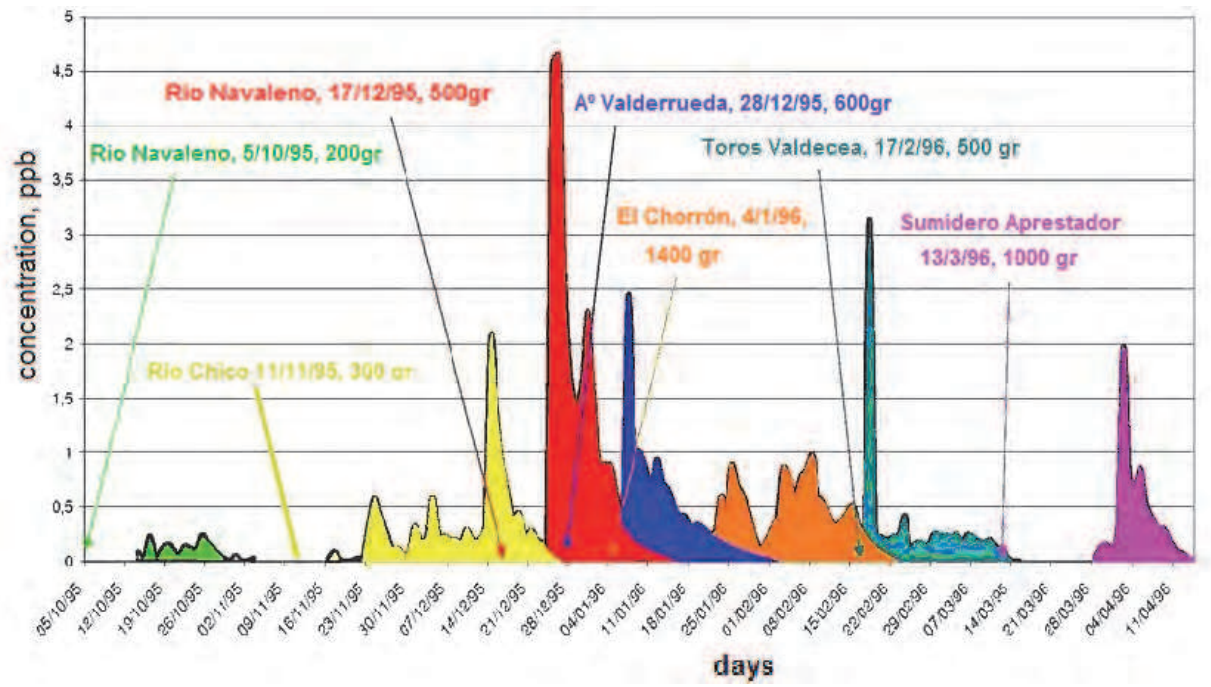

Fig. 4. Response curves concentration-time for different tracer tests. 


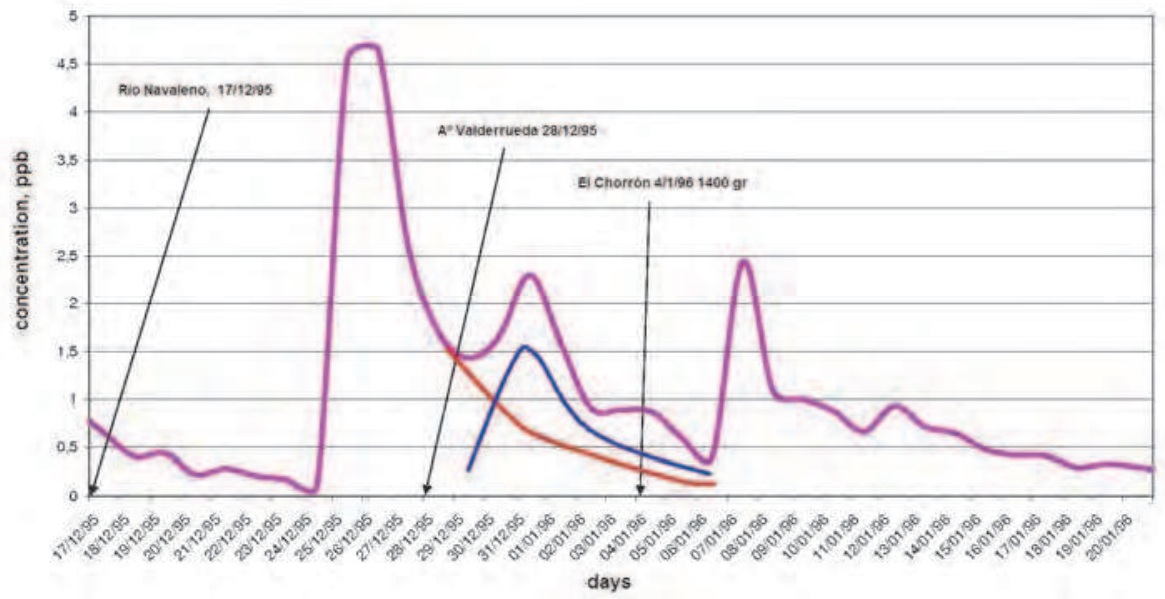

Fig. 5. Response curve detailed at La Galiana spring and Lobos River for testing Navaleno River, Arroyo de Valderrueda and Chorrones sink.

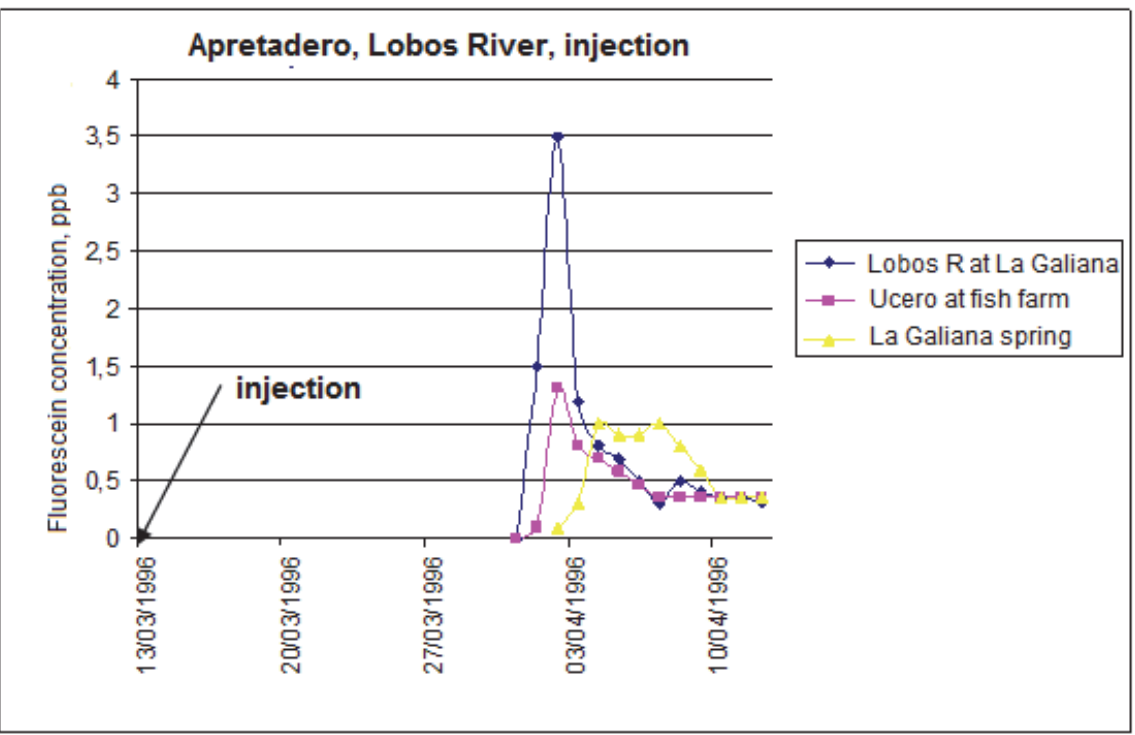

Fig. 6. Concentration-time in response curve for test in Lobos River, Apretadero sink place.

Under flood water conditions, the river Lobos contains water along the entire canyon. In its upstream $6 \mathrm{~km}$, between the head of the canyon and the Puente de Siete Ojos, the river now acts as a gaining stream. This occurs as a consequence of producing copious ephemeral surcharges that drain a hanging syncline. In 2000, a tracer test confirmed the existence of a rapid, local flow between the groundwater flow from a cave called Sima del Portillo de 
Hontoria to the principal of these springs (Las Raideras). In the reach between Puente de Siete Ojos and the San Bartolomé hermitage, more or less, the river is always a losing stream, as evidenced by differential gauging, and by the fact that the tracers did not appear here. The limit of the hermitage is approximate because, as the phreatic level rises again, it is the intersection between this and the watercourse that separates the losing and gaining parts of the river. As the river usually contains a great flow, it is difficult to appreciate this transition and the only way to check it is using tracers. Between the hermitage and La Galiana spring the river is a gaining stream, as shown by the appearance of the tracer substance.

\subsection{Typology of the tracer curves}

Although the curves overlap at times (when two tracer tests were run successively), in general it is possible to separate one from the other a grosso modo, as indicated tentatively in Figure 4.

Four of the curves (tracer injections in the river Navaleno on 17/12/95, and at Valderrueda, Torca de Valdecea and El Apretadero) follow the typical normal distribution, with an steeply-ascending arm and a steeply-descending arm. All the curves have the two peaks mentioned above: a principal wave followed by a much smaller one. It seems that this type of curve occurs mostly, though not exclusively, under flood and intermediate flow conditions.

However, three curves did not follow this pattern:

The first injection into the river Navaleno swallow hole (5/10/95) gave a serrated curve, which we attribute more to the poor ability of the fluorometer to detect low concentrations of tracer (only a small amount of uranine was used given the low water conditions).

The curve resulting from dye injection into the Chorrón sinkhole produced two clear peaks, with the second one, paradoxically, being larger than the first. It is difficult to interpret this feature, which once again, points to the complexity of karstic systems. It may have been due to a bifurcation in flow but, more probably, that the tracer plume was split into two plumes by the recharge caused by intense rainfall during the tracer test that caused a sharp change from low flow conditions to flood flow. The direction of groundwater flow coincides with the direction of flow in the river Lobos, so that the tracer plumes pass beneath the riverbed and, sometimes, beneath its tributaries. The recharge produced when these losing streams are carrying water can interfere and distort the geometry of the tracer plume.

The response curve for the tracer test in the river Chico under low flow conditions indicates low flow velocity and a long retention time of the plume within the aquifer. The curve has three peaks - two small ones followed by a larger one - all contrary to what is the norm. It is possible that, here, there were a number of bifurcations in flow, a phenomenon that is more common under a low water regime. The test cannot be repeated in this watercourse under flood water conditions because the river flow obliterates the swallow holes.

Two small response curves apparently have no correspondence to any of the tracer tests. These were recorded on 27/10/1996 and 8/02/1996, (Figure 5). The plume of 8/02/1996 can be explained by the rainfall and consequent spate in the river Lobos which washed out tracer remaining from the previous tests; this is a fair assumption as the plume coincides with an increase in the hydrogram recorded at La Galiana and in the river Lobos at Puente de Siete Ojos. The other plume $(27 / 10 / 96)$ can be explained in the same way, though it occurred much later than the tracer tests and was not accompanied by any flood flow. It is relevant to note that the aquifer was "contaminated" by the fluorescein used in the second 
tracer test, which was translated as an increase in background concentration at both La Galiana and river Lobos springs.

\subsection{Velocity of groundwater flow}

According to the tests undertaken, the actual velocity of groundwater oscillated between around $460 \mathrm{~m} /$ day to more than 3,000 m/day. This attests to the high water velocity close to the Galiana spring and in more distant zones, both under high and low water conditions. Figure 7 shows the variation in groundwater velocity as a function of spring flow at La Galiana. It shows how the velocity of groundwater flow varies from low to high water conditions as a function of the phreatic level and natural recharge. As expected in karstic aquifers, phreatic level and recharge shows wide oscillation and this is reflected in the hydrogram for La Galiana spring as well as in the water levels in the borehole at Puente de Siete Ojos.

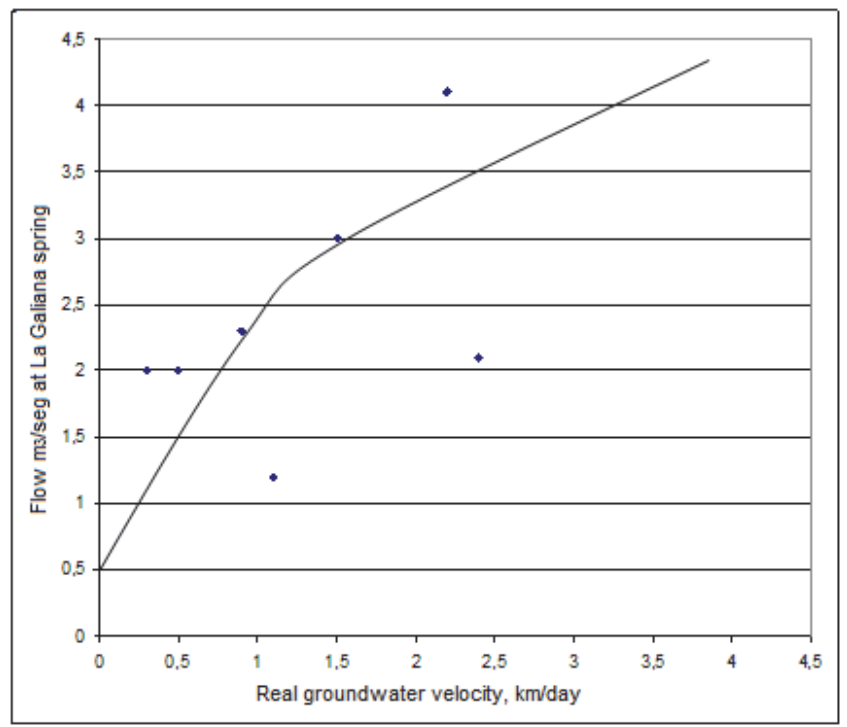

Fig. 7. Relationship of groundwater velocity and flow at La Galiana

Figure 8 shows the variation in groundwater velocity with respect to distance to the main discharge point at La Galiana. Two curves are shown - one for high water (rainy spells) and one for intermediate flow (drier spells). From these, a rough estimate can be made of the isochrones which, in the middle of the aquifer (which lies about $9 \mathrm{~km}$ from La Galiana), vary quite markedly - from 21 days for low water and 4 days under high water conditions. In other words, the hydrodynamic regime varies widely according to rainfall and recharge.

It also seems that flow velocity varies according to the direction of flow. The river Casarejos is the only point where flow is orthogonal to the general direction of flow and this supposes that groundwater flows sub-parallel to the axis of the canyon and at a lower velocity. This suggests certain anisotropy, since the velocity along the axis of the canyon (flowing northwest - south-west) is four times that flowing NE-SW. This feature is unsurprising because it makes sense that karstification has developed preferentially along the river, along the 
vertical plane that is hydrodynamically most active and where the greatest inflows and outflows to the aquifer occurred through the Quaternary.

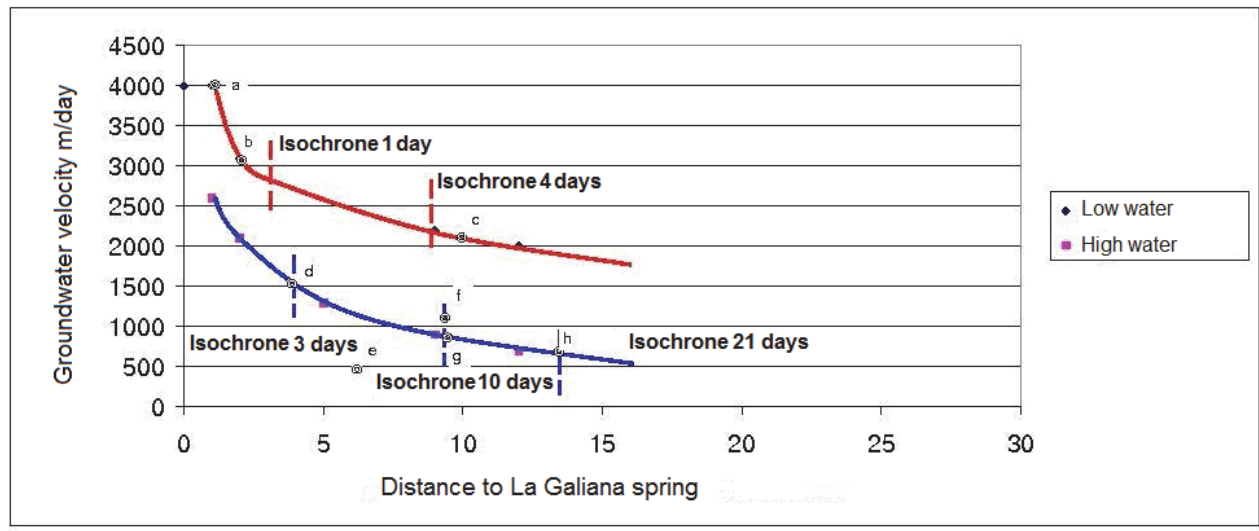

a. Arroyo de Valderrueda- Lobos River

b. Valdecea- La Galiana spring y Lobos River

c. Sumidero del Chorrón- La Galiana spring

d. Arroyo de Valderrueda- La Galiana spring

e. Chico River- La Galiana spring

f. Navaleno River- La Galiana spring

g. Navaleno River- La Galiana spring

h. Lobos River (Apretadero)- La Galiana spring

Fig. 8. Variation of groundwater velocity depending on the distance to La Galiana and isochrones calculation.

\subsection{Turbidity as a natural tracer}

The spring water emerging at La Galiana is normally clear but after very heavy rainfall it can become turbid. We observed two cases where the turbidity of this spring water could be used informally as a natural tracer, and allowed some conclusions to be drawn about the vulnerability of the aquifer to pollution:

During the torrential rainfall of December 1995 and January 1996 the river Lobos reached a peak flow of $30 \mathrm{~m}^{3} / \mathrm{s}$, flooding the entire canyon, whilst five or six days after the flood in the river, there was a rapid and significant increase in turbidity in the spring water issuing from La Galiana. This reflects a groundwater "flood" in the hypogeic drainage within the aquifer.

While the water in the river cleared a few days after the peak of the flood, the turbidity in the spring water persisted for one or two weeks more, until it too gradually cleared.

This interesting feature is illustrated in Figure 9 as a flow-turbidity response curve, alongside similar curves for conductivity and time. Measurements were made ex profeso, using the samples taken for the artificial dye tracer tests. The curves in figure enable the following observations:

- Turbidity follows a normal distribution, which fits the peak of the La Galiana hydrogram quite well. 
- This turbidity curve is delayed by 5-6 days compared to the peak of the flood in the river Lobos.

- Remobilization of clays in the endokarst and from allogenous streams indicate erosion and a considerable capacity of hypogeic transport. During these periods, both the turbulent flow regime and the circulation through karstic conduits must be very significant.

- The conductivity curve is the inverse of the flood flow and turbidity, as is to be expected.

The turbidity during spate underlines the vulnerability of the aquifer to pollution under flood conditions, showing how a large quantity of contaminants, allogenous or autogenous, could be transported through the aquifer over a short period. It also indicates a marked capacity for self-purification and for natural contamination by the turbidity itself; in fact, the fish farm had to close its water intake for several days when the turbidity was greatest in order to protect the trout.

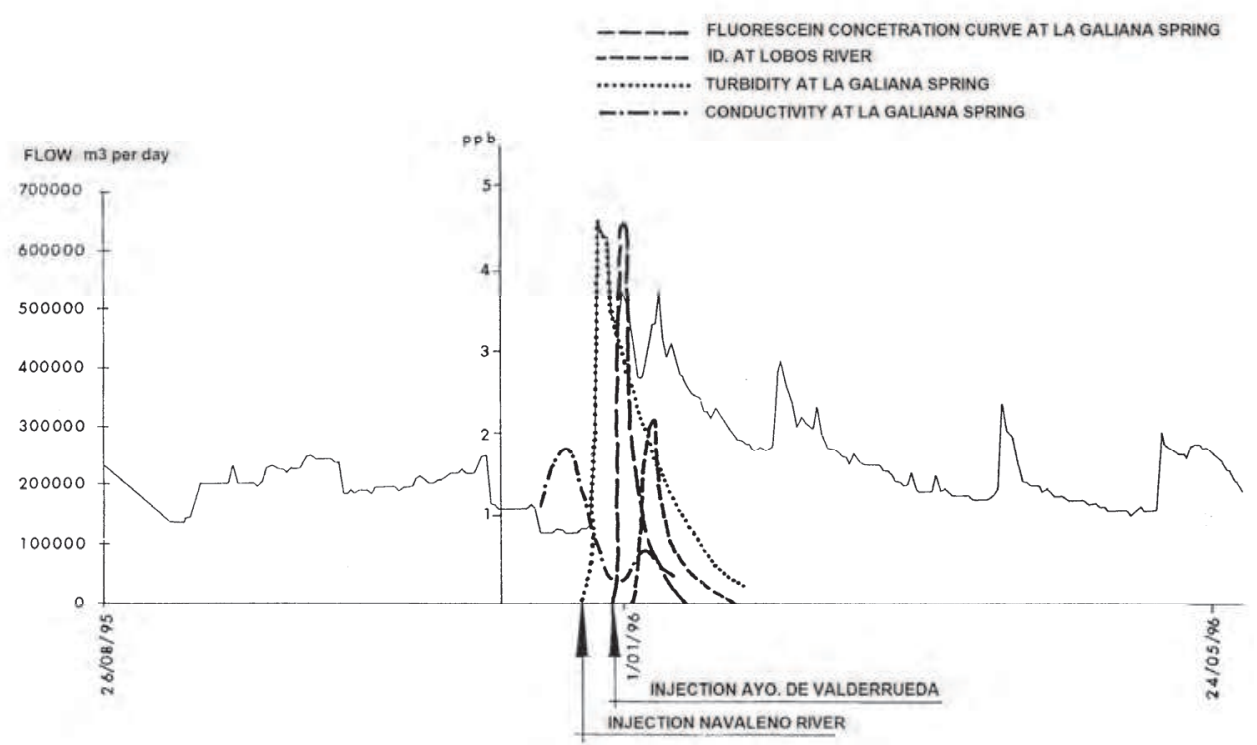

Fig. 9. Turbidity curves, conductivity and flow. La Galiana sping. (floods in december 95 to january 96)

Over the period 18 May to 7 June 2005, when practically no rain fell, the spring water at La Galiana was continually whitish in colour. This is very different from the red colour produced during natural floods. On this occasion, the cause of the turbidity was quite different, and due to the drilling and subsequent development of two wells to supply three villages (3580 permanent population and 8600 summer population), very close to each other. These were drilled very close to each other in April 2005 by rotary drilling, to depths of $275 \mathrm{~m}$ and $280 \mathrm{~m}$ at a distance of some $7 \mathrm{~km}$ from La Galiana spring. The boreholes penetrated thick deposits of white limestone and marly limestone and both the tailings and the water extracted during the drilling and development were drained 
directly into the watercourse (C.M.A. - J.C.L., 2006). From here they infiltrated the aquifer and were left hanging with respect to the position of the phreatic level. From 21 to 25 April, the boreholes were developed using pistons and compressed air, and it was this water, very turbid and milky, that was discharged into the watercourse. Without doubt, these four days of continuous development of the borehole are what caused the turbidity at La Galiana. What is interesting is that the plume took 27 days to appear at this spring, and lasted for about 20 days. All this took place under a low water regime; the "tracer" had to penetrate the unsaturated zone through sectors of matrix flow and where permeability was not necessarily very high at the beginning: this explains why the plume took so long to appear at La Galiana. The water velocity was calculated to have been 262 $\mathrm{m} /$ day. In contrast, the remaining tracer tests were carried out from injection points in river beds that lay very close to the saturated zone and in sectors that certainly contained developed conduits.

This is a good example of a tracer test from the surface of the meseta and it demonstrates the sensitivity of the aquifer to drilling and development of wells. It took the Natural Park Authorities by surprise, and, from 18 May to 7 June, the intake to the La Galiana fish farm had to be changed to take water from the river Lobos (which had not been visibly affected by the turbidity). Obviously, there was no option to call a halt to the borehole work, since this had been completed more than a month previously.

\subsection{Mass of tracer recovered}

Since some of the response curves from the tracer tests overlapped, it would have been difficult to separate the tracer recovery for each individual test. Instead, the cumulative recovery was calculated. This indicates that $3,300 \mathrm{~g}$ of the $4,500 \mathrm{~g}$ were accounted for, or $73.3 \%$. It is clear that the remainder was retained in the ground. Some of this tracer is released during spells of intense rain, as occurred around the 8/02/96. This retention is not surprising since both the saturated and unsaturated zone of the aquifer, as well as the alluvium of the river where the injections were made, hold abundant clays (as confirmed by the turbidity increases described above).

The low concentrations recovered is also noteworthy, despite the volume of tracer used (sometimes $1.5 \mathrm{~kg}$ ), and this indicates both that the aquifer stores considerable volumes of water and that significant dispersion must occur. Segovia (2008) estimated permanent reserves of $203 \mathrm{hm}^{3}$ and a refill rate of 2.55 years.

\subsection{Hydrodynamic dispersion}

It is recognized that the tracer mixture is displaced through a porous medium in three ways: carried along by the current to which it is added; molecular diffusion; and dispersion through the porous medium, whereby the tracer molecules take different paths through the conduits, dispersing it both longitudinally and transversely.

Taking the retention times of the tracer in the aquifer an approximate estimate was made of the parameters involved in longitudinal dispersion. Logically, these vary with distance. The graph in Figure 10 shows that there is a linear relationship between the distance of the injection point from the emergence point at La Galiana. This gives an approximate "longitudinal dispersion", which is measured from the leading edge of the plume to the end of its tail. The retention time of the dye in the aquifer and the average flow velocity in each tracer test is taken into account and the response curves deduced. 


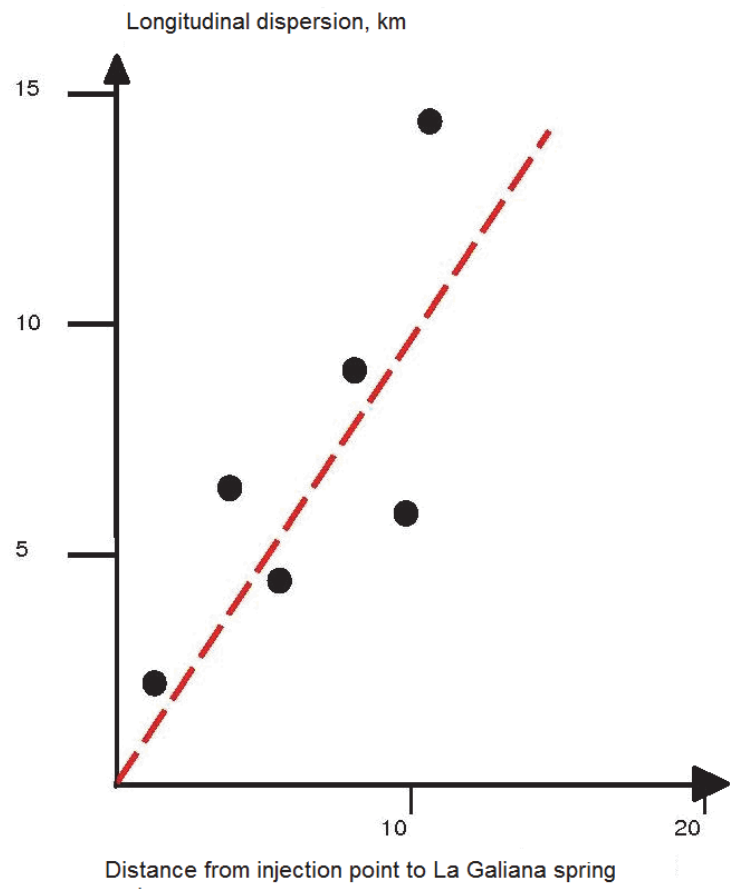

Fig. 10. Relationship between longitudinal dispersion and distance from La Galiana spring to each tracer injection point.

\subsection{Observations on the vulnerability of the aquifer to pollution}

In this section we outline some qualitative and semi-quantitative ideas. (We do not aim to calculate the transfer and evolution of pollution plumes to enable transit times to be calculated along with the predicted falls in pollutant concentration for point or diffuse pollution events.)

The first point to note is the very high velocity of the groundwater. Also, all of the preferential conduits (which is the network of conduits supposedly investigated in the tracer tests) would give residence times of less than one month, whatever the hydrological regime. Consequently, bacterial or viral pollutants could survive in the aquifer. This is an important point because there are several villages situated over the aquifer, and although these have wastewater treatment works, there could always be accidental or illegal spills of wastewater, or from farm slurry (pig and sheep purines).

The water flowing through the karst is extremely vulnerable. An accidental spill to the rivers that recharge the aquifer, or to any intermediate point within the calcareous outcrop, would contaminate the water that emerges from the aquifer at La Galiana and the lower reaches of the river Lobos, to some extent.

The dispersive effect of the aquifer is significant. It increases with distance from the spring under a low flow regime, with a NE-SW orientation. Closer to the discharge, and under high 
water conditions, the curves are more unimodal in form. Where water levels are very high, the aquifer is vulnerable to acute turbidity "crises", and it is also very sensitive to turbidity arising from drilling of boreholes.

The aquifer has not demonstrated any self-purification capacity, except for the partial retention of tracer due, undoubtedly, to the absorption onto clay particles of alluvial deposits.

\section{Conclusions}

It is a relatively frequent occurrence, in hydrogeological practice, to search karst aquifers little known, little used, but with large resources. It is also quite common that these systems are connected, in some way, by allogenic surface rivers. For these cases we have proposed a methodology that can provide in a short period of time some key issues for future management, such as the hydrogeological conceptual model, knowledge about hydrodynamics and flow, water balance and preliminary assessment for risk of contamination.

The proposed method basically includes the following: hydrogeological interpretation of geological mapping, numerous tracer tests, control of allogenic river flows that recharge the aquifer and measures in the discharge capacity of the aquifer.

The methodology has been applied to the Lobos River Canyon karst system during one hydrological year and it was obtained the following more relevant results:

The tracer tests confirm the hydrogeological basin initially defined by geology. This is an area of Upper Cretaceous carbonate outcrops of $160 \mathrm{~km}^{2}$ which forms an unconfined aquifer structured in a moderate syncline and is verified natural recharge of $42.2 \mathrm{hm}^{3}$. Allogenic rivers provide a recharge of $53.7 \mathrm{hm}^{3}$. The discharges are carried out mainly by the spring of La Galiana, and a little by Lobos river.

The groundwater velocity varies between 460 and $3.000 \mathrm{~m} /$ day depending on rainfall regime and increases with proximity to the La Galiana spring and as far as flow is subparallel to the axis of the syncline.

The tracer tests were used to find the connection Lobos river along $26 \mathrm{~km}$ through the aquifer in the canyon and in different hydrological situations. In case of low water table, the river Lobos and tributaries loose through simple sinks at headwater and only carries water on its final discharge path, where is also the source of La Galiana. In this case, sinksunderground discharges communication is showed. Hydraulic conductivity of sediment channel plays an important role in connection between Lobos river and aquifer.

Knowing spatial variation of groundwater velocity, is showed that hydraulic conductivity increases with proximity to aquifer outpoint, and also with direction. This one is greater in longitudinal direction to the flow, along the syncline, showing the heterogeneity of karst.

In high rainfall regime and in the header stretch of the canyon, the river becomes an effluent one, and its waters are traced. The intermediate stretch is a influent river and tracers do not show up, and at the final stretch, river is an effluent one. It emphasizes the high groundwater velocity. Also notorious is the fact that the whole preferential conduit net of the aquifer is located within the perimeter where residence time is less than a month in any hydrological regime. Therefore, any bacterial or viral contamination will survive in this aquifer. This is important because this aquifer system is located downstream of several villages. Although they have got wastewater treatment works, always could be accidental or illegal spills of wastewater or pig or beef cattle manure and slurries. 
The dispersive effect in the aquifer is significant. It increases with distance from the discharge system in low rainfall regime and with NE-SW direction. Closer to the discharge, and under high water conditions, the response curves are more unimodal in form. It should be noted the existence of potential turbidity crises in water regime very high. The aquifer is also very sensitive to turbidity arising water from drilling of boreholes

\section{Acknowledgements}

We should like to thank the director of the Natural Park of the River Lobos Canyon, Don José Manuel Meneses Canalejo, for all the help given during field studies, from assistance obtaining necessary permissions, to help from the Natural Park rangers for water sampling during the tracer tests, taking readings at the gauging stations that they installed, etc. We should also like to thank the Confederación Hidrografica del Duero for giving permissions to undertake the tracer tests. Part of this investigation formed part of of Research Project AMB95-0154: "Hydrodynamic Function and Pollution Propagation in the karstic aquifer of the Natural Park of the River Lobos Canyon (Soria - Burgos)".

\section{References}

Birk S, Geyer T, R and Sauter M (2005) Process-based interpretation of tracer tests in carbonate aquifers. Ground Water 43(2): pp. 381-388.

C.M.A. - J.C.L. (Consejería de Medio Ambiente y Ordenación del Territorio - Junta de Castilla y León) (1992). Plan Rector de Uso y Gestión del Parque Natural “Cañón del río Lobos". Unpublished report. $457 \mathrm{pp}$.

C.M.A. - J.C.L. (Consejería de Medio Ambiente y Ordenación del Territorio - Junta de Castilla y León) (2006) Informe sobre los sondeos realizados en la obra: Navaleno, Casarejos, y San Leonardo de Yagüe. Abastecimiento Mancomunado. Clave: 21 - 50 - 202. Uxama Ingeniería y Arquitectura S. L.

COST 65 (1995) Hydrogeological aspects of groundwater protection in karstic areas, Final report (COST Action 65). European Commision, Directorate-General XII-Science, Research and Development, Report EUR 16547 EN, Brussels, 446.

Fournier, M., Massei, N., Bakalowicz, L. Rodet, S. and Dupont, J. P. (2007). Using turbidity dynamics and geochemical variability as a tool for understanding the behavior and vulnerability of a karst aquifer. Hydrogeology Journal, 15: 689 - 704.

Geyer, T., Birk, S., Licha, T.,R. and Sauter, M. (2007) Multitracer test approach to characterize reactive transport in karst aquifers. Ground Water. 45(1): pp. 36-45.

Goldscheider N, Klute M, Sturm S, Hötzl H (2000) The PI method: a GIS-based approach to mapping groundwater vulnerability whit special consideration of karst aquifers. $\mathrm{Z}$. Angew Geol 463: pp. 157-166.

Goldscheider, N. (2005) Karst groundwater vulnerability mapping: application of a new method in the Swabian Alb, Germany. Hydrogeology Journal 13(4): pp. 555-564.

Goldscheider, N., Meiman, J., Pronk, M., and Smart, C. (2008) Tracer tests in karst hydrogeology and speleology. International Journal of Speleology 37(1): pp. 27-40.

González - Yélamos, J. (1999): Ensayos de trazadores en acuíferos kársticos: desarrollo histórico y anecdotario. In: Carrasco, F.; Duran, J.J. and Andreo, B. (Eds). Karst and Enviroment, 75 - 83. 
Göppert, N., Goldscheider, N. (2008) Solute and Colloid Transport in karst conduits under low and high flow conditions. Ground Water, 46(1): pp. 61-68.

Hauns, M., Jeannin, P-Y, and Atteia, O. (1991) Dispersion, retardation and scale effect in tracer breakthrough curves in karst conduits. Hydrogeology Journal. 24(3-4): pp. 177-193.

Hernanz, A. and Navarro, J. M. (1973). La Cueva de La Galiana, Ucero (Soria). Revista Celtiberia $\mathrm{n}^{\mathrm{o}} 19, \mathrm{pp} .87-92$.

IGME (Instituto Geológico y Minero de España)(1982). Mapa Geológico de España 1/50.000. Hoja 349. Cabrejas del Pinar.

IGME (Instituto Geológico y Minero de España) (1982). Mapa Geológico de España 1:50.000 Hoja 348. San Leonardo de Yagüe

Käss, W. (1998) Tracing techniques in geohydrology. Balkema, Rotterdam, The Netherlands.

Massei N, Wang HQ, Field MS, Dupont JP, Bakalowicz M, and Rodet J (2006) Interpreting tracer breakthrough tailing in a conduit-dominated karstic aquifer. Hydrogeology Journal. 14(6): pp. 849-858.

Meus, P. and Bakalowicz, M. (1997). Les traçages artificiels, outils de reconnaissance et f'étudedes aquifières karstiques. Hidrogéologie n³, 43 - 50 .

Morales T, Valderrama IF, Uriarte JA, Antigüedad I, and Olazar M (2007) Predicting travel times and transport characterization in karst conduits by analysing tracerbreakthrough curves. Hydrogeology Journal. 15(1): pp. 183-198.

Panno SV (2006) Karst aquifers: can they be protected? Ground Water 44(4): p. 494.

Perrin J and Luetscher M (2008) Inference of the structure of karst conduits using quantitative tracer tests and geological information: example of the Swiss Jura. Hydrogeology Journal. 16(5): pp. 951-967.

Segovia, R (2008). El drenaje subterráneo en el acuífero kárstico del Caños del río Lobos (Soria-Burgos). Tesis Doctoral(Inédita).Universidad Politécnica de Madrid.

Sanz, E. (1992). Las aguas subterráneas en el Parque Natural del Cañón del río Lobos (Soria - Burgos). Boletín Geológico y Minero. Vol. 103 - 102, 309 - 329

Sanz, E. (1996). Le karst du canyon du Lobos et son fonctionnement hydrogéologique. Karstología, nº 28, $45-56$.

Sanz, E. (2000). Infiltration measured by the dripping of stalactites. Groundwater, volume $38, n^{\circ} 2,247-253$.

Smart CC (1988) Artificial Tracer techniques for the determination of structure of conduit aquifers. Ground Water 26(4): pp. 445-453.

Zwahlen F (ed) (2004) Vulnerability and risk mapping for the protection of carbonate (karst) aquifers, final report (COST action 620). European Commission, DirectorateGeneral XII Science, Research and Development, Brussels. 


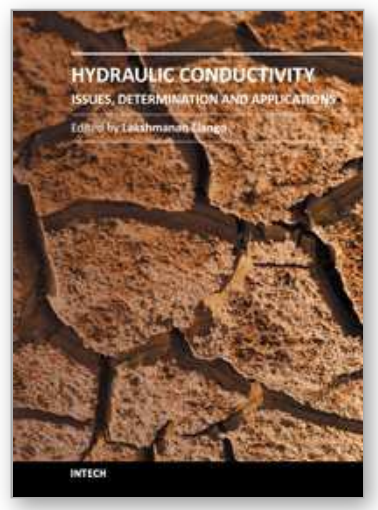

\author{
Hydraulic Conductivity - Issues, Determination and Applications \\ Edited by Prof. Lakshmanan Elango
}

ISBN 978-953-307-288-3

Hard cover, 434 pages

Publisher InTech

Published online 23, November, 2011

Published in print edition November, 2011

There are several books on broad aspects of hydrogeology, groundwater hydrology and geohydrology, which do not discuss in detail on the intrigues of hydraulic conductivity elaborately. However, this book on Hydraulic Conductivity presents comprehensive reviews of new measurements and numerical techniques for estimating hydraulic conductivity. This is achieved by the chapters written by various experts in this field of research into a number of clustered themes covering different aspects of hydraulic conductivity. The sections in the book are: Hydraulic conductivity and its importance, Hydraulic conductivity and plant systems, Determination by mathematical and laboratory methods, Determination by field techniques and Modelling and hydraulic conductivity. Each of these sections of the book includes chapters highlighting the salient aspects and most of these chapters explain the facts with the help of some case studies. Thus this book has a good mix of chapters dealing with various and vital aspects of hydraulic conductivity from various authors of different countries.

\title{
How to reference
}

In order to correctly reference this scholarly work, feel free to copy and paste the following:

Rafael Segovia Rosales, Eugenio Sanz Pérez and Ignacio Menéndez Pidal (2011). Contribution of Tracers for Understanding the Hydrodynamics of Karstic Aquifers Crossed by Allogenic Rivers, Spain, Hydraulic Conductivity - Issues, Determination and Applications, Prof. Lakshmanan Elango (Ed.), ISBN: 978-953-307288-3, InTech, Available from: http://www.intechopen.com/books/hydraulic-conductivity-issues-determinationand-applications/contribution-of-tracers-for-understanding-the-hydrodynamics-of-karstic-aquifers-crossed-byallogenic

\section{INTECH}

open science | open minds

\section{InTech Europe}

University Campus STeP Ri

Slavka Krautzeka 83/A

51000 Rijeka, Croatia

Phone: +385 (51) 770447

Fax: +385 (51) 686166

www.intechopen.com

\section{InTech China}

Unit 405, Office Block, Hotel Equatorial Shanghai

No.65, Yan An Road (West), Shanghai, 200040, China 中国上海市延安西路65号上海国际贵都大饭店办公楼405单元

Phone: +86-21-62489820

Fax: +86-21-62489821 
(C) 2011 The Author(s). Licensee IntechOpen. This is an open access article distributed under the terms of the Creative Commons Attribution 3.0 License, which permits unrestricted use, distribution, and reproduction in any medium, provided the original work is properly cited. 